\title{
Contextualized Bilingualism in the Republics of Southern Siberia
}

\author{
Tamara G. Borgoiakova and Aurika V. Guseinova* \\ N.F. Katanov Khakass State University \\ Abakan, Russian Federation
}

Received 02.02.2020, received in revised form 08.02.2021, accepted 09.04.2021

\begin{abstract}
The article examines the development of bilingualism in the Republics of Southern Siberia. Its social context is formed under the influence of both extralinguistic factors and the language hierarchy in the form of vertical bilingualism. According to the latest sociolinguistic surveys, bilingualism is the norm for indigenous peoples - Altaians, Tuvans and Khakass - and their language behavior is determined by a strong instrumental and integrative motivation for using Russian as a language of social promotion. The increase of the subtractive type of bilingualism has resulted in the exclusive use of Russian not only in the external, but also in the internal circle of communication with the highest rates in the Republic of Khakassia (about 60 and 30\%, respectively). A pragmatic attitude influences the language behavior: the more indigenous respondents declare their fluency in Russian, the fewer of them speak their native language. At the same time, the languages of the titular peoples retain a high symbolic status, expressed in recognition of native languages and in willingness to contribute to their support and promotion.
\end{abstract}

Keywords: bilingualism, indigenous languages, language policy, Khakassia, Tuva, Altai.

The research is supported by the Russian Foundation for Basic Research (RFBR), project "Dynamics and prospects of languages interaction in the Republics of Southern Siberia" No. 20-012-00426.

Research area: philology.

Citation: Borgoiakova, T.G., Guseinova, A.V. (2021). Contextualized bilingualism in the Republics of Southern Siberia. J. Sib. Fed. Univ. Humanit. Soc. Sci., 14(4), 466-477. DOI: 10.17516/1997-13700734 .

\footnotetext{
(C) Siberian Federal University. All rights reserved

* Corresponding author E-mail address: tamarabee@mail.ru, aurika_guseynova@mail.ru ORCID: 0000-0001-9958-9086 (Borgoiakova); 0000-0001-9708-114X (Guseinova) 


\title{
Контекстуализированный билингвизм в республиках Южной Сибири
}

\author{
Т.Г. Боргоякова, А.В. Гусейнова \\ Хакасский государственный университет имени Н. Ф. Катанова \\ Российская Федерачия, Абакан
}

\begin{abstract}
Аннотация. В статье исследуется развитие билингвизма в республиках Южной Сибири. Его социальный контекст формируется под влиянием как экстралингвистических факторов, так и языковой иерархии в форме вертикального билингвизма. Согласно последним социолингвистическим опросам, билингвизм является нормой для коренных народов - алтайцев, тувинцев и хакасов - и их языковое поведение определяется сильной инструментальной и интегративной мотивацией использования русского языка в качестве языка социального продвижения. Усиление замещающего типа билингвизма привело к исключительному использованию русского языка не только во внешнем, но и во внутреннем кругу общения с самыми высокими показателями в Республике Хакасия (около 60 и 30 \% соответственно). Прагматический подход влияет на языковое поведение: чем больше респондентов из числа коренных народов заявляют о своем владении русским языком, тем меньше из них говорят на родном языке. В то же время языки титульных народов сохраняют высокий символический статус в глазах их носителей, выражающийся в признании родных языков и в готовности содействовать их поддержке и продвижению.
\end{abstract}

Ключевые слова: билингвизм, языки коренных народов, языковая политика, Хакасия, Тыва, Алтай.

Исследование выполнено при финансовой поддержке Российского фонда фундаментальных исследований (РФФИ), проект «Динамика и перспективы языкового взаимодействия в республиках Южной Сибири» № 20-012-00426.

Научная специальность: 10.00 .00 - филологические науки.

\section{Introduction}

The problem of preserving linguistic diversity was actualized by the UN General Assembly through the declaration of 2019 the International Year of the indigenous languages in order to stimulate urgent measures to preserve, revive and promote them (About IYIL, 2019). The lessons of the International Year will influence the upcoming Decade of Indigenous Languages (2022-2032), prioritizing the empowerment of native speakers of indigenous languages. These actions are necessary, in part, because "existing laws and policies have proven inadequate to redress the legacy of state suppression of indigenous languages or ensure nondiscrimination in contemporary usage" (Carpenter, Tsykarev, 2020).
The language legislation of the Russian Federation, created in the early 1990 s, became the normative and legal foundation of the language policy of democratic orientation. It led to a significant increase in the status-symbolic role of the titular indigenous languages of the republics of the Russian Federation. However, the results of expanding the social functions of the state languages of the republics of the Russian Federation were less successful (Zamyatin, 2019).

The purpose of this paper is the analysys of the bilingualism development in the changing social contexts of the neighboring Turkic-speaking republics of Southern Siberia (RSS) - Khakassia, Tuva and Altai. The relevance of the study is connected with the on- 
going processes of language shift among the speakers of the titular languages of the RSS, despite their high status of state languages in the corresponding republics.

The focus is made on the peculiarities of the influence of the changing social context on language attitudes, language behavior, based on the data of sociolinguistic surveys, conducted in Khakassia (RKh), Tuva (RT) and Altai (RA) in 2020 with coverage of 3,000 respondents (1,000 in each republic).

The ratio of informants in terms of their ethnicity is roughly in line with the structure of the population of the republics with a predominance of Russians in the RKh and RA (Russians $-81.7 \%$ and $56.6 \%$ respectfully), and Tuvans in the RT (Tuvans - 82\%) (Vserossiiskaia perepis naseleniia, 2010).

\section{Statement of the Problem}

The official discourse of the three neighboring republics in the context of federal language legislation has already been the subject of comparative analysis in (Borgoiakova, 2002; Borgoiakova, 2015; Borgoiakova, Guseynova, $2019 b)$. It is noted there that the federal legal basis of the language policy is based on the unconditional dominant of the Russian language with a minimum level of requirements and recommendations for the republican and local languages functioning. In addition, the commonality of the "soft" version of the language legislation of the RSS and the gradation by the level and number of domains in which the studied languages function, in addition to the Russian language, were revealed. This allows us to characterize bilingualism in the RSS as vertical or asymmetric, as the superiority of the national Russian language and the peripheral significance of the republican languages are officially confirmed. This means, as V. Tishkov claims, that for the non-Russian population in Russia the most acceptable and desirable norm is "bilingualism or multilingualism in many of its variants with Russian used as the first or the second language" (Tishkov, Akbaev 2019: 25).

For the indigenous peoples of the RSS Altaians, Tuvans and Khakass - bilingualism is a norm supported by instrumental motivation - wanting to learn Russian for utilitarian reasons. Integrative motivation in respect of native languages correlates with the feeling of positive ethnic identity, which is strong but different among the representatives of titular nations of the RSS.

Different types or variants of bilingualism prevail in the republics, depending on the level of language assimilation of their indigenous languages, which co-function with the dominant Russian language. In the sociolinguistic classifications of the languages of the peoples of the Russian Federation, the assessment of the vitality and prospects of the state languages of the RSS varies greatly. Thus, the Tuvan language in different classifications is ranked both as "functionally developed" with a high level of vitality and as "vulnerable". The assessment of the vitality of the Khakass and Altai languages also varies from "sufficiently high" to "causing concern" (Moseley, 2010; Iazyk i obshchestvo, 2016). This is due to the fact that in Russian sociolinguistics simple mono-factorial, one-line classifications of languages are common: by the number of native speakers, by the number of social functions performed by the language, by the presence/absence of writing tradition and the time of its adoption, by the presence/absence of legal and functional status (Mikhal'chenko, 2019: 8). In the sociolinguistic typology of the state languages of the RSS in (Borgoiakova, 2002) the following rating of their vitality is presented: the Tuvan language has the highest level, the Altai language is in the second place and the Khakass language - in the third.

Further study of the development of bilingualism and obtaining new knowledge about the real processes of language shift in the context of asymmetric bilingualism actualizes the need to attract new data to establish the types of bilingualism based on its contextualization using empirical methods.

\section{Discussion}

\section{Language Attitudes}

As D. Daoust underlines, it is hard to evaluate the time-related impact of "unguided sociolinguistic forces", which dictate the course of action, and to assess if it is to be attributed to language policies. So evaluation of language - 
planning policies can best be done through their symbolic impact - "in the long run, it is attitudes which lead to change" (Daoust, 1998: 451). To evaluate the beliefs and values expressed by people towards languages of RSS in terms of favorability and unfavorability, questions of the surveys were aimed at revealing the awareness of the status of languages, the acceptance of a native language, as well as the attitudes to the teaching of the RSS languages at school and the willingness to contribute to their preservation.

The answers to the question about a language or languages with an official state status in the RSS are presented in Fig. 1.

The presented data shows that the greater the percentage of the Russian population in the republic, the more of its respondents indicated that the only state language in the region is Russian. Perhaps the reason for this is that the smaller the share of the titular ethnic group in the republic, the less its population is aware of the language problems of the region and, accordingly, the legal status of the language of the titular people as the state language. On the other hand, the bigger the share of titular residents, the more of the respondents know about the high state status of both languages (Russian and titular) in their Republics. As seen from Fig. 1, respondents of the RT are the most informed of this.
Another aspect of the language attitude is the recognition of ethnic languages as native. The results of a sociolinguistic survey of Khakass, Tuvans and Altaians are presented in Fig. 2.

As Fig. 2 shows, the highest level of recognition of the ethnic language as their native one is demonstrated by the Tuvan respondents (about 90\%). The indicators of the surveyed Altaians are ten percent lower, behind which, in turn, the Khakass respondents are nine percent behind. At the same time, it looks quite logical that the largest percentage of those who recognize as their native languages Russian $(10 \%)$ and Russian and Khakass (18.4\%) is among the Khakass, in second place - Altaians (5.6\% and $13.9 \%$, respectively), and the minimum percentage of those who recognize Russian as their native language is observed in the group of respondents of Tuvan origin $(1.9 \%$ and $8.1 \%$, respectively).

The overwhelming majority of Russian respondents (over $98 \%$ in the $\mathrm{RKh}$, more than $90 \%$ in the RA, over $78 \%$ in the $\mathrm{RT}$ ) recognize their ethnic language as their native. Among the Russian respondents in the RT, $13.5 \%$ indicated Tuvan as their native language, and $6.8 \%$ - Russian and Tuvan; in the RA, 3.3\% of Russian respondents consider the Altai language as their native language, $5.4 \%$ - Russian and Altai. In the RKh, only $1.5 \%$ of Russian

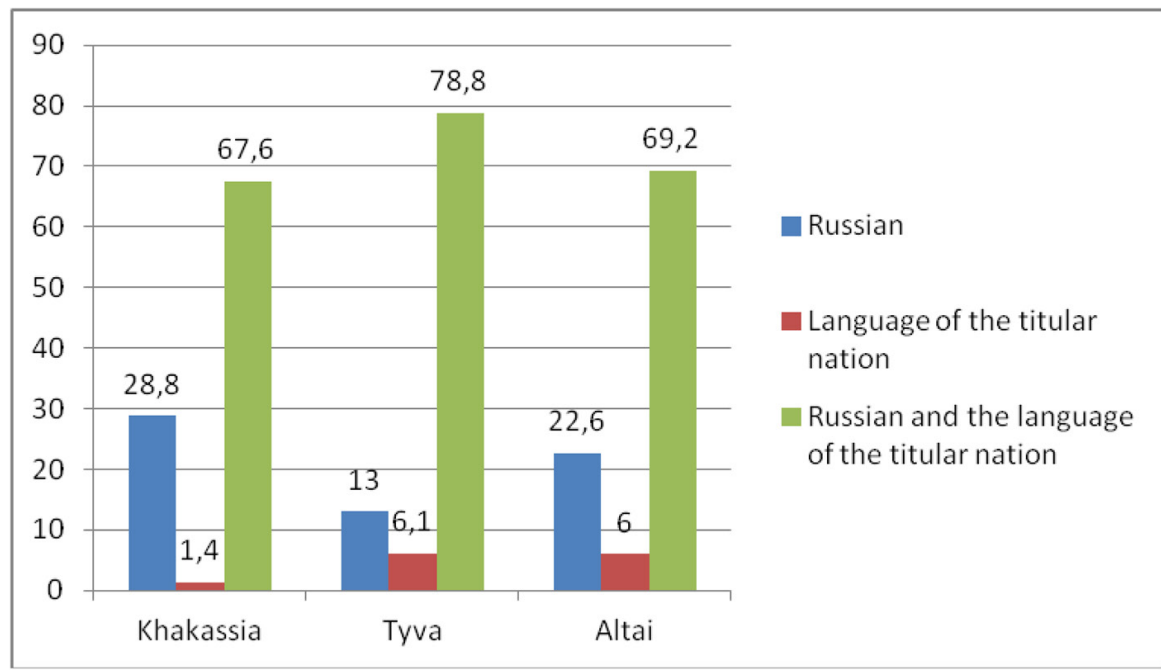

Fig. 1. State languages of the RSS (according to the sociolinguistic survey 2020), \% 


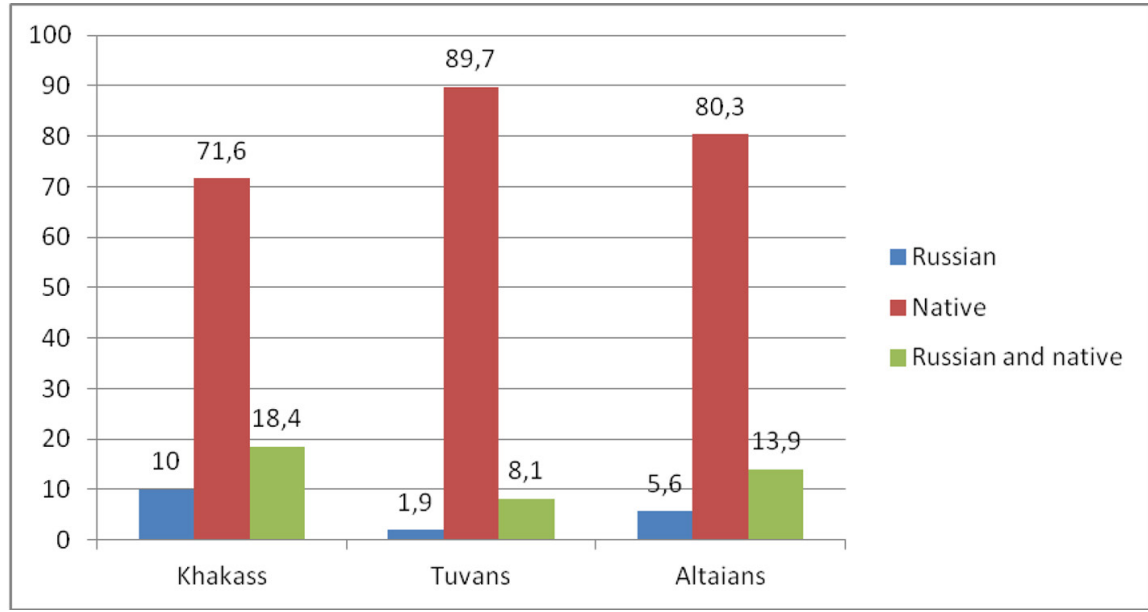

Fig. 2. Native Languages of Indigenous Peoples of the RSS (according to the sociolinguistic survey 2020), \%

respondents consider Khakass as their native language or as one of the two native languages. The highest level of the competence in the languages of the titular peoples of RSS is demonstrated by Russian respondents in the RT - almost $19 \%$ of them reported that they speak Tuvan fluently, while among the Russian respondents in RA this indicator is $2.8 \%$, and in the $\mathrm{RKh}-2.3 \%$. Perhaps this correlates with the level of need for the integration of the Russian population into the local community context. Thus, the influence of the ethno-demographic structure of the population in the autonomies of Southern Siberia on the language attitudes has been revealed again.

The next block of questions in the questionnaire was aimed at clarifying the language attitudes of the residents of the RSS through their opinion about teaching the RSS indigenous languages at school and their willingness to contribute to these languages support and preservation. Its results are presented in Table 1.

As it turned out, the overwhelming majority of the respondents of the RSS - both of Russian and titular origin - consider it necessary that Khakass, Tuvan and Altai children should have the opportunity to study their native languages at school. As Table 1 shows, the highest level of support for the study of the language of the titular people of the RSS at school was demonstrated by the respondents of the Russian and Khakass origin, which indicates that the reason to worry about the future of the Khakass - the second state language of the $\mathrm{RKh}-$ is evident.

There were significantly fewer supporters of introducing the compulsory study of the republican titular languages, especially among the Russian respondents. Attention draws the significant difference in the opinions of Russian respondents: less than a quarter of Russian respondents in the $\mathrm{RKh}$, where Russians make up more than $80 \%$, and almost $40 \%$ of Russian respondents in RT, where more than $80 \%$ are Tuvans, answered positively to this question.

The respondents showed an ambiguous attitude towards the issue of their readiness to support the preservation and development of the republican languages. It turned out that the stronger its position, the more Russian respondents support it, and the weaker the position of the language, the greater its support on the side of native speakers. According to Table 1, the highest level of support for the Khakass language was expressed by the titular people $(93.3 \%)$ and the lowest - on the part of the Russian-speaking majority of the $\mathrm{RKh}$ (38.7\%). A different picture is observed in the RT: $78.1 \%$ of Tuvans and $46 \%$ of Russians are ready to contribute to the preservation and development of the Tuvan language. However, 
Table 1. Language attitudes in the RSS

\begin{tabular}{|l|c|c|c|c|c|c|}
\hline \multicolumn{1}{|c|}{ Statements } & \multicolumn{2}{c|}{ Khakassia } & \multicolumn{2}{c|}{ Tuva } & \multicolumn{2}{c|}{ Altai } \\
\cline { 2 - 7 } & RR* & KhR* & RR & TR* & RR & AR* \\
\hline $\begin{array}{l}\text { Children of indigenous peoples of the RSS should learn their } \\
\text { mother tongue at school }\end{array}$ & 82 & 98.4 & 70.3 & 94 & 79.3 & 94.6 \\
\hline $\begin{array}{l}\text { Learning of the second official republican language should be } \\
\text { obligatory for all pupils }\end{array}$ & 23.4 & 73.9 & 39.2 & 71.8 & 36.6 & 78 \\
\hline $\begin{array}{l}\text { Ready to contribute to the preservation of the second official re- } \\
\text { publican language }\end{array}$ & 38.7 & 93.3 & 46 & 78.1 & 39.5 & 88.9 \\
\hline
\end{tabular}

$R^{*}$ - Russian respondents; KhR* - Khakass respondents; $T R^{*}$ - Tuvan respondents; $A R^{*}$ - Altai respondents.

the gap between the level of support for the republican language from the Russian and the titular peoples in all three republics is large and amounts to more than $30 \%$ in Tuva, more than $40 \%$ in Altai, more than $50 \%$ in Khakassia.

At the same time, on average, $77 \%$ of Russian respondents of the RSS are convinced that Khakass, Tuvan and Altai children should be able to study their native language at school, but only $34 \%$ agree with the need to introduce compulsory learning of these languages. On average $41 \%$ are ready to support them. In our opinion, these data indicate the absence of hostility of the Russian population of the RSS towards the languages of the titular peoples, combined with a rather indifferent attitude towards them and their future.

The other aspect of the language attitude is the level of the ability to use the languages of the titular peoples on the part of Russian respondents. It is extremely low in the RA with only $2.8 \%$ of RR reporting that they can speak Altaic fluently, in the RKh - only $2.3 \%$ Russians are fluent in the Khakass language. RT is the exception - almost $19 \%$ of Russian respondents declared to be fluent in Tuvan. Undoubtedly, the attitude of the Russian-speaking population makes an unfavorable social context, influencing the development of bilingualism in the RSS.

\section{Language Behavior}

As noted above, language attitudes and settings determine language behavior. Below is a summary of the respondents' responses to the questions about the level of their language competence and the intensity of use in various communication contexts.

The data presented in Fig. 3, shows that respondents are better at passive types of speech activity (understanding and reading) than active ones (speaking and writing), but the gap is no more than $10 \%$. In general, this data indicates a different level of additive bilingualism in the RSS, when the Russian component of bilingualism has not supplanted the native languages. According to the respondents' self-assessment, the level of fluency in all types of speech activity in the Khakass language is more than $50 \%$, in Altai - more than $60 \%$, and in Tuvan - about $80 \%$.

As for the level of fluency in the Russian language on the part of the indigenous population of the RSS (see Fig. 4), the lowest percentage is characteristic of the RT $(47.7 \%)$. In the $\mathrm{RKh}$ it is $86.6 \%$, in the RA $-80.1 \%$. Half of the respondents of Tuvan origin assessed their level of Russian language proficiency as average $(45.7 \%)$ and elementary (4.5\%). It should be noted that the revealed regularity (the more respondents of the indigenous origin declare their fluency in Russian, the less fluent they are in the second state language in this region) can be explained by the instrumental and integrative motivation to learn the language of social promotion.

As for the assessment of the language competence in Russian by the Russian population of the RSS, more than $90 \%$ of the respondents assessed its level as fluent. This percentage turned out to be the highest in the RT $-95.9 \%$.

It is interesting to compare the results of our 2020 questionnaire with Fig. 5 (Baskakov, 


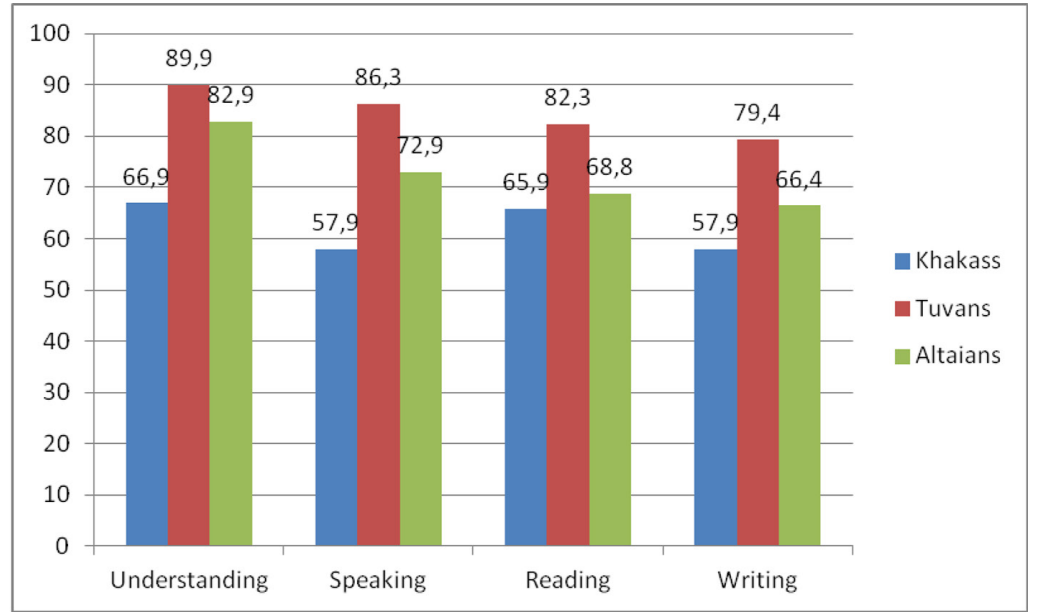

Fig. 3. Indigenous Peoples of the RSS language competence in the mother tongue

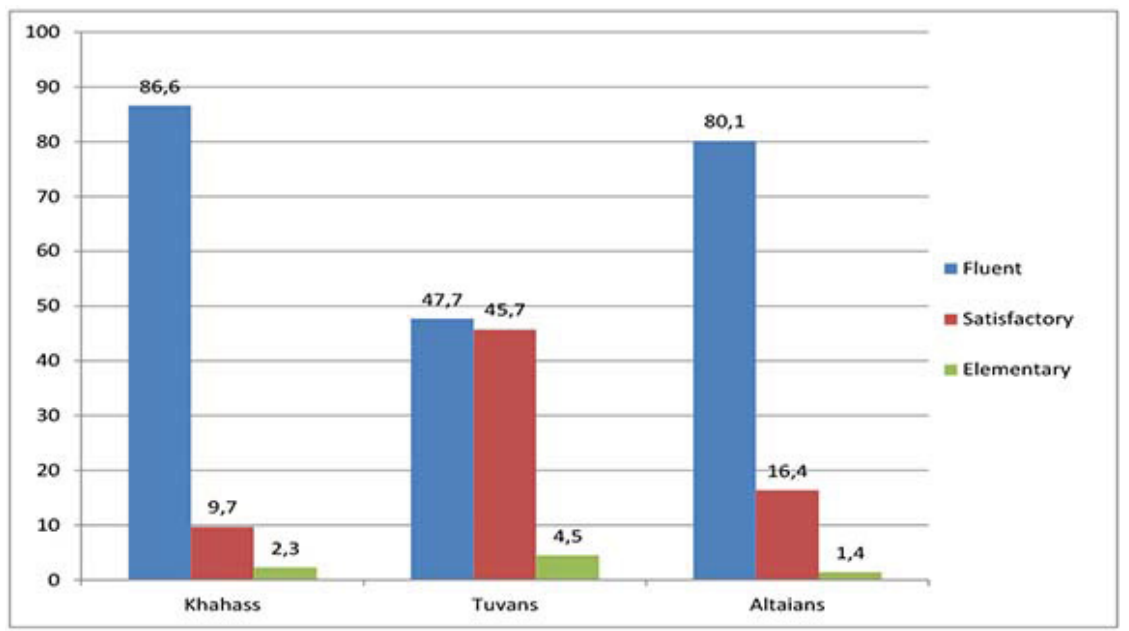

Fig. 4. Language competence of Indigenous Peoples of the RSS in Russian (according to the sociolinguistic survey 2020), \%

Nasyrova, 2000), which presents the results of the population censuses from 1970 to 1994. Since 1994 the indices of the Khakass and Altaians fluency in Russian have increased by $10 \%$ and $7 \%$, respectively, but among Tuvans they have more than $15 \%$ decreased. Perhaps this decline is due to changes in the ethno-demographic situation in Tuva, when a significant percentage of the Russian population left the Republic in the first post-Soviet years (see also (Kan, 2016)).

The next block of questions is devoted to the use of the state languages of the RSS in various domains. The results are presented in Table 2.

As can be seen from Table 2, the most active respondents from among the indigenous peoples of the RSS use their native languages to communicate with the older generations: parents and grandparents. At the same time, the Khakass use both Khakass (36.1\%) and Russian and Khakass (35\%), with almost the same intensity when communicating with their parents, while Tuvans and Altaians have a much greater preponderance towards using exclusively their native language. 


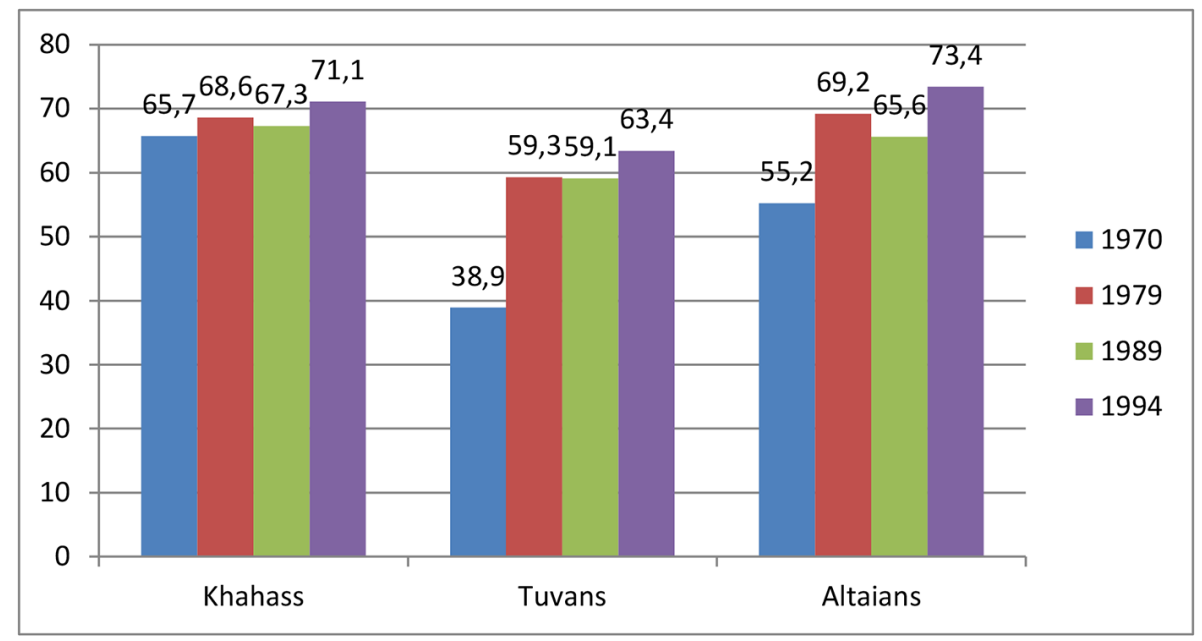

Fig. 5. Indigenous Peoples of the RSS fluent competence in Russian (according to the Soviet and Russian censuses), \%

Table 2. Usage of Southern Siberian languages in different domains (according to the sociolinguistic survey 2020), \%

\begin{tabular}{|c|c|c|c|}
\hline Domains & KhR & TR & AR \\
\hline $\begin{array}{l}\text { Communication with parents: } \\
\text { in the mother tongue } \\
\text { both in the mother tongue and in Russian }\end{array}$ & $\begin{array}{l}36.1 \\
35.5\end{array}$ & $\begin{array}{c}69.2 \\
27\end{array}$ & $\begin{array}{l}49.1 \\
39.6\end{array}$ \\
\hline $\begin{array}{l}\text { Communication with grandparents: } \\
\text { in the mother tongue } \\
\text { both in the mother tongue and in Russian }\end{array}$ & $\begin{array}{l}47.8 \\
31.8\end{array}$ & $\begin{array}{l}85.4 \\
11.4\end{array}$ & $\begin{array}{l}65.0 \\
27.1\end{array}$ \\
\hline $\begin{array}{l}\text { Sociolizing with friends: } \\
\text { in the mother tongue } \\
\text { both in the mother tongue and in Russian }\end{array}$ & $\begin{array}{c}6.7 \\
52.8\end{array}$ & $\begin{array}{l}36.8 \\
57.1\end{array}$ & $\begin{array}{c}13.2 \\
72\end{array}$ \\
\hline $\begin{array}{l}\text { Communication with colleagues: } \\
\text { in the mother tongue } \\
\text { both in the mother tongue and in Russian }\end{array}$ & $\begin{array}{c}8 \\
43.5\end{array}$ & $\begin{array}{c}25.6 \\
65\end{array}$ & $\begin{array}{c}8.3 \\
57.6\end{array}$ \\
\hline $\begin{array}{l}\text { Contacting public institutions: } \\
\text { in the mother tongue } \\
\text { both in the mother tongue and in Russian }\end{array}$ & $\begin{array}{c}1.4 \\
15.7\end{array}$ & $\begin{array}{l}11.8 \\
53.8\end{array}$ & $\begin{array}{c}6.3 \\
26.9\end{array}$ \\
\hline $\begin{array}{l}\text { Getting acquainted with media materials: } \\
\text { in the mother tongue } \\
\text { both in the mother tongue and in Russian }\end{array}$ & $\begin{array}{c}0.7 \\
53.2\end{array}$ & $\begin{array}{c}3.2 \\
60.8\end{array}$ & $\begin{array}{c}2.5 \\
47.0\end{array}$ \\
\hline
\end{tabular}

The most active use of the state languages of the RSS within the family is revealed in the communication with grandparents: $85 \%$ of the polled Tuvans, $65 \%$ of the Altaians and almost half of the Khakass use their native language with them. It should be noted that more than a third of the Khakass and about a third of the
Altaians also use Russian in addition to their native language, while only $11.4 \%$ of Tuvans use both Russian and Tuvan for this purpose.

The respondents of the titular nations use their native languages to speak to their friends in comparatively active way, but only simultaneously with the Russian language (at least 
$50 \%$ of respondents in each region). At the same time, $36.8 \%$ of the polled Tuvans communicate with their friends only in the Tuvan language, while over $40 \%$ of the Khakass use only Russian for this purpose. The highest rate of communication with friends in two languages - Russian and native languages - is represented among the Altaians - more than $70 \%$.

The next domains of communication make the so-called external circle (communication with colleagues, contacting governmental agencies, acquaintance with the media, etc.). As Table 2 shows, the majority of respondents communicate with colleagues in two languages: Russian and their native language (the only exception here are the Khakass, $48.5 \%$ of whom speak only Russian with colleagues, while $43.5 \%$ speak Russian and Khakass). The Tuvan respondents have the highest level for the exclusive use of their native language in communication with colleagues $(25.6 \%)$ and the lowest indicator for the use of exclusively Russian $(7.7 \%)$. It seems that this can be explained again by the ethno-demographic composition of the RSS, where the largest percentage of the Russian population lives in the RKh, the smallest - in the RT, and therefore the chance of working in a team, consisting exclusively of representatives of the titular ethnic group, is much higher in Tuva. As for Khakassia and Altai, in addition to the lower level of proficiency in the second state languages in these republics, they also have a larger percentage of the Russian population, which determines the wider use of the Russian language among staff members.

The language of appeal to state institutions and organizations in the RKh is mainly Russian. Only $15.7 \%$ of Khakass respondents reported that they use both Russian and Khakass languages in this field, while more often Russian or only Russian - more than $80 \%$ in total. A similar situation is observed in the RA, however, there more than a quarter of the Altaians surveyed apply to state institutions and organizations in Russian and Altai. In the RT, more than half of the Tuvans use both state languages in this area, which indicates a wider representation of the Tuvan language in the official domains.
The data of the sociolinguistic survey indicate that the respondents of the titular ethnic groups of the RSS prefer media products in two languages - Russian and their native languages. At the same time, about half of the Khakass and Altai respondents get acquainted with media content exclusively in Russian, while among Tuvans this figure is $35 \%$.

The social determinism of the development of regional bilingualism becomes obvious when analyzing the intensity of the Russian language use in the above spheres, which can be combined into internal (family and friends) and external circles. The strengthening of the substitute type of bilingualism among the speakers of the titular languages of the RSS is primarily manifested in the external circle, as evidenced by the data on the use of only the Russian language in it, which is 59\% among the KhR residents, 50\% among the AR residents and $26.6 \%$ among the TR residents. This type of language behavior, dictated by the external linguistic context, leads to the displacement of the native languages into the internal circle of communication. However, even there, almost a third $(29.7 \%)$ of the KhR residents use only Russian, while among the AR population this indicator is $11.2 \%$, and among the TR population $-4.4 \%$.

\section{Evaluation of Language Polices in the RSS}

Several questions of the survey were devoted to evaluation of the language policy effectiveness in the RSS. A large number of interviewed Khakass, Altaians and Tuvans assess it positively, answering "yes" and "rather yes" to the question "Do the authorities of the republic provide effective support to the Khakass / Tuvan / Altai language?": 57.9\%, 61.2\% and $45.5 \%$ respectively, and "no" and "probably not" $-25.8 \%$ of Khakass, $31 \%$ of Tuvans and $22 \%$ of Altaians.

The republican language policy is considered effective by $55.4 \%$ of Russian respondents in the RKh, $51.7 \%$ in the RA, and $36.5 \%$ in the RT. It is interesting to note that Russian respondents answered positively to this question less often than respondents of titular nationalities. There were more of those dis- 
satisfied with the republican language policy among the inhabitants of Tuva (both Tuvans and Russians) than among the respondents from Khakassia and Altai, although the position of the Tuvan language, as was mentioned above, is recognized as the strongest in the RSS. More than $30 \%$ of Russian respondents in all three regions did not answer this question, saying that it is difficult to define. This may indicate their indifference or ignorance about the measures taken by the authorities to support the second state languages.

The rating of the importance of the subjects of the language policy in the RSS was compiled on the basis of the analysis of the respondents' answers to the question: "On whom / what, in your opinion, the future of the Khakass / Tuvan / Altai language depends in the first place?". It turned out that the previously revealed pattern was confirmed in part (Borgoiakova, Guseinova, 2019a), according to which the residents of the RSS consider native speakers and the republican authorities to be the most important subjects of language policy.

The results obtained made it clear that the weaker the position of a regional language, the more inclined are the inhabitants of the region to blame the responsibility for its future on its speakers. In the RKh and the RA, more than half of the respondents of both Russian and indigenous origin consider their speakers to be responsible for the future of the republican languages, while in RT this figure is $43.2 \%$ for
Russian respondents and $50.5 \%$ for Tuvans. RSS media discourse analyses in (Borgoiakova, Guseinova, 2021) also revealed this search for those guilty in the language shift to Russian as one of the leading toposes or argumentative lines. It should be noted that the respondents of the titular nations pointed to the responsibility of the native speakers for the future of their languages, on average, $10 \%$ more often than the Russian respondents. The highest rate of blaming native speakers was found among the $\mathrm{KhR}$ residents $(76.6 \%)$.

The republican authorities are in the second place in the rating - their leading role in preserving the minority languages of the RSS was noted by about a third of respondents from the RKh and the RT and almost a quarter from the RA. As for the rest of the subjects of language policy, there are some regional differences. Thus, respondents from the RKh and RA assess the contribution of the federal authorities to the future of the languages of their republics significantly higher than those from the RT; the attitude of the Russian-speaking population also turned out to be more significant for them than for respondents from the RT. At the same time, the influence of school on the preservation of the native language seems to be less significant to respondents from the RKh and RT than from the RA. It is noteworthy that the respondents of the titular peoples assign the least role in the future of the RSS languages to the Russian-speaking majority of the RF.

Table 3. Rating of the role of subjects of language policy in the RSS

\begin{tabular}{|c|c|c|c|c|c|c|}
\hline & \multicolumn{6}{|c|}{ Who / what, in your opinion, primarily determines the future of the language? } \\
\hline & $\begin{array}{c}\text { Federal } \\
\text { government }\end{array}$ & $\begin{array}{l}\text { Republican } \\
\text { government }\end{array}$ & $\begin{array}{l}\text { Russian-speak- } \\
\text { ing majority }\end{array}$ & School & $\begin{array}{c}\text { Native } \\
\text { speakers }\end{array}$ & Don't know \\
\hline \multicolumn{7}{|c|}{ Khahassia } \\
\hline RR & 11.2 & 31.5 & 10.9 & 9.4 & 65.9 & 9.9 \\
\hline KhR & 23.4 & 33.8 & 6.4 & 12 & 76.6 & 4 \\
\hline \multicolumn{7}{|l|}{ Tuva } \\
\hline RR & 1.4 & 33.8 & 5.4 & 9.5 & 43.2 & 10.8 \\
\hline TR & 7.7 & 22.2 & 1.5 & 15.6 & 50.5 & 9.7 \\
\hline \multicolumn{7}{|c|}{ Altai } \\
\hline RR & 13.9 & 19.6 & 9.4 & 13.9 & 51 & 15.7 \\
\hline AR & 18.1 & 30.8 & 3.7 & 19.2 & 66.7 & 6.5 \\
\hline
\end{tabular}




\section{Conclusion}

The development of bilingualism in the RSS is determined by the social context of languages functioning and language attitudes. The social context was formed under the influence of historical and demographic extra linguistic factors and the official language hierarchy in the form of vertical bilingualism. As current sociolinguistic surveys in the RSS have shown, the language behavior of bilinguals is determined by a strong instrumental and integrative motivation for using the Russian language as a language of social advancement. As a result, there is an increase of the subtractive type of bilingualism, when the indigenous population uses exclusively Russian not only in the external, but also in the internal circle of communication with the highest indicators in the RKh (about $60 \%$ and $30 \%$, respectively). The influence of a pragmatic attitude on language behavior is obviously seen in the pattern: the more respondents among the indigenous peoples of the region declare their fluency in Russian, the less they speak their native language.
Positive evaluation of the republican language policy correlates with the tendency of shifting the responsibility for the future of the indigenous languages of RSS onto the native speakers. Hopes for the strengthening of not a substractive, but additive type of bilingualism are associated with the persisting high symbolic status of the native languages for the indigenous population, which is expressed in their recognition of native languages and in willing to contribute to their support and promotion. Prospects are also related to the tasks of the forthcoming International Decade of Indigenous Languages (2022-2032) to improve the effectiveness of states in correcting the negative consequences of the displacement of indigenous languages from active life in the past.

\section{Acknowledgements}

We express our gratitude to Mira BavuuSurun (Kyzyl, Republic of Tuva) and Alexey Chumakaev (Gorno-Altaisk, Republic of Altai) for cooperation and conducting sociolinguistic surveys in the respective republics.

\section{References}

About IYIL (2019). Available at: https://en.iyil2019.org (accessed 14 January 2021)

Baskakov, A.N., Nasyrova, O.D. (2000). Iazykovye situatsii v tiurkoiazychnykh respublikakh Rossiiskoi Federatsii (kratkii sotsiolingvisticheskii ocherk) [Language situations in the Turkic-speaking republics of the Russian Federation (a brief sociolinguistic essay)]. In Iazyki Rossiiskoi Federatsii i novogo zarubezh'ia: status i funktsii [Languages of the Russian Federation and the new abroad: status and functions], 34-129

Borgoiakova, T.G. (2002). Sotsiolingvisticheskie protsessy v respublikakh Iuzhnoi Sibiri [Sociolinguistic processes in the republics of Southern Siberia]. Abakan, Izdatel'stvo Khakasskogo gosudarstvennogo universiteta im. N.F. Katanova, 166 p.

Borgoiakova, T.G. (2015). Iazykovaya politika v respublikakh Iuzhnoi Sibiri: Altai, Tyva, Khakasiia [Language policy in the republics of Southern Siberia: Altai, Tyva, Khakassia]. In Iazykovaya politika v kontekste sovremennykh iazykovykh protsessov [Language policy in the context of modern language processes], 118-132.

Borgoiakova, T.G., Guseinova, A.V. (2019a). Dinamika iazykovogo povedeniia i iazykovykh ubezhdenii v kontekste iazykovoi politiki respubliki Khakasiia [Dynamics of linguistic behaviour and linguistic views in the context of language policy in the republic of Khakassia]. In Filologicheskie nauki: voprosy teorii i praktiki [Philological sciences. Issues of theory and practice], 12 (11), 342-347. DOI: https://doi. org/10.30853/filnauki.2019.11.72

Borgoiakova, T.G., Guseinova, A.V. (2019b). Language policy in university education: the case of Khakassia and Tyva. In Journal of Siberian Federal University. Humanities and Social Sciences, 12 (10), 1796-1818. DOI: 10.17516/1997-1370-0489

Borgoiakova, T.G., Guseinova, A.V. (2021). Otsenochnye aspekty obsuzhdeniia iazykovoi politiki v mediinom diskurse respublik Iuzhnoi Sibiri [Evaluation aspects of the language policy in the media dis- 
course of the republics of Southern Siberia]. In Filologicheskie nauki. Nauchnye doklady vysshei shkoly [Philological sciences. Scientific essays of higher education], 1, 21-27. DOI: 10.20339/PhS.1-21.021.

Carpenter, K., Tsykarev, A. (2020). (Indigenous) Language as a Human Right. In UCLA Journal of International Law and Foreign Affairs, 24 (49). Available at: https://ssrn.com/abstract=3649091 (accessed 14 January 2021)

Daoust, D. (1998). Language Planning and Language Reform. In F. Coulmas (ed.) The handbook of sociolinguistics, 436-452. Blackwell Publishers Ltd.

Iazyk $i$ obshchestvo. Entsiklopediia [Language and Society. Encyclopedia] (2016). Moskow, Azbukovnik, $872 \mathrm{p}$.

Kan, V.S. (2016). Etnosotsial'nyi profil' tuvintsev [Ethnosocial profile of Tuvans]. In Novye issledovaniia Tuvy [New research of Tuva], 2, 52-72. Available at: https://nit.tuva.asia/nit/article/view/94/437 (accessed 15 January 2021)

Mikhal'chenko, V.Iu. (2019). Sotsiolingvisticheskii aspekt klassifikatsii iazykov Rossii [Sociolinguistic classification of the languages of Russia]. In Iazyki v polietnicheskom gosudarstve: razvitie, planirovanie, prognozirovanie. Mezhdunarodnaia konferentsiia (Ulan-Ude - Goriachinsk, 1-4 iiulia 2019 g.): doklady $i$ soobshcheniia [Languages in a polyethnic state: development, planning and prospects: International Conference (Ulan-Ude-Goriachinsk, 1-4 July 2019): Reports and communication], 8-12.

Moseley, C. (2010). Atlas of the World's Languages in Danger, 3rd edn. Paris, UNESCO Publishing. Available at: http://www.unesco.org/languages-atlas/ (accessed 18 January 2021)

Tishkov, V.A., Akbaev Kh.M. (2019). "Narod ne umiraet s iazykom" ili "Iazyk ne zhivet bez naroda"? Dialog uchenykh o konflikte vokrug rodnogo iazyka ["The people don't die with the language" or "The language doesn't live without the people"? Dialogue of scholars about the conflict over the native language]. In Smert' iazyka - smert' naroda? Iazykovye situatsii i iazykovye prava v Rossii i sopredel'nykh gosudarstvakh [Is the death of the language the death of the people? Language situations and language rights in Russia and neighboring states]. Moscow, Institut etnologii i antropologii im. N.N. Miklukho-Maklaia RAN, Goriachaia liniia - Telekom, 19-39.

United Nations Declaration on the Rights of Indigenous Peoples. Available at: https://undocs.org/A/ RES/61/295 (accessed 14 January 2021)

Vserossiiskaia perepis naseleniia 2010 [All-Russia population census 2010]. Available at: https://rosstat.gov.ru/free_doc/new_site/perepis2010/croc/perepis_itogi1612.htm (accessed 12 January 2021)

Vserossiiskaia perepis naseleniia 2002 [All-Russia population census 2002]. Available at: http://www. perepis2002.ru/index.html?id=11 (accessed 12 January 2021)

Zamyatin, K. (2019). Evaluating Language Revival Policies of Russia's Finno-Ugric Republics: Policy Impact and Its Limits. In Finnisch-Ugrische Forschungen, 2018 (64), 255-333. DOI: https://doi. org/10.33339/fuf.66530 